\title{
Summer Abundance and Distribution of Proteorhodopsin Genes in the Western Arctic Ocean
}

\author{
Dominique Boeuf ${ }^{1,2}$, Raphaël Lami ${ }^{3,4}$, Emelyne Cunnington ${ }^{1,2}$ and Christian Jeanthon ${ }^{1,2 *}$ \\ ${ }^{1}$ CNRS, Station Biologique, UMR 7144 Adaptation and Diversité en Milieu Marin, Roscoff, France, ${ }^{2}$ Sorbonne Universités - \\ UPMC Université Paris 06, Station Biologique, UMR 7144 Adaptation and Diversité en Milieu Marin, Roscoff, France, \\ ${ }^{3}$ CNRS, USR 3579, Laboratoire de Biodiversité et Biotechnologies Microbiennes, Banyuls-sur-Mer, France, ${ }^{4}$ Sorbonne \\ Universités - UPMC Université Paris 06, USR 3579, Observatoire Océanologique, Banyuls-sur-Mer, France
}

Proteorhodopsins (PR) are phylogenetically diverse and highly expressed proton pumps in marine bacterial communities. The phylogenetic diversity and in situ expression of the main PR groups in polar off-shore, coastal and estuarine waters is poorly known and their abundance has not yet been reported. Here, we show that PR gene sequences of the southern Beaufort Sea including MacKenzie shelf and estuary are mainly affiliated to Gammaproteobacteria, Alphaproteobacteria, and Bacteroidetes. Substantial overlap (78\%) between DNA- and cDNA-based librairies indicated in situ PR transcription within

OPEN ACCESS

Edited by:

Hongyue Dang,

Xiamen University, China

Reviewed by:

Heather Bouman,

University of Oxford, UK

John Phillip Bowman,

University of Tasmania, Australia

*Correspondence:

Christian Jeanthon

jeanthon@sb-roscoff.fr

Specialty section: This article was submitted to Aquatic Microbiology,

a section of the journa

Frontiers in Microbiology

Received: 02 June 2016 Accepted: 21 September 2016

Published: 13 October 2016

Citation:

Boeuf D, Lami R, Cunnington E and Jeanthon C (2016) Summer Abundance and Distribution of Proteorhodopsin Genes in the Western Arctic Ocean.

Front. Microbiol. 7:1584. doi: 10.3389/fmicb.2016.01584 a large fraction of PR-containing community. Sets of specific qPCR primers were designed to measure the absolute abundances of the major PR types. Spatial and depth profiles showed that PR-containing bacteria were abundant throughout the photic zone, comprising up to $45 \%$ of total bacteria. Although their abundance varied greatly with location and depth, Alphaproteobacteria predominated in the PR community in all water masses, with SAR11 as the major PR type. Low nutrient concentrations rather than light were the environmental drivers that best explained the abundance and distribution of arctic PR types. Together, our data suggests that PR-based phototrophy could be the major phototrophic prokaryotic process during the Arctic Ocean summer.

Keywords: proteorhodopsin, photoheterotrophy, SAR11, Arctic Ocean, Mackenzie River

\section{INTRODUCTION}

Proteorhodopsins (PRs) are prokaryotic retinal-binding integral membrane proteins that function as light-driven proton pumps. Culture-based experiments suggested their implication in various bacterial physiological functions, including ATP generation (Fuhrman et al., 2008), survival processes in nutrient-depleted conditions (Gómez-Consarnau et al., 2010; Steindler et al., 2011; Akram et al., 2013) or light sensing (Jung et al., 2003). After its initial discovery on a large genomic fragment derived from an uncultured marine gammaproteobacterium of the SAR86 clade (Béjà et al., 2000), PRs have been found in a diversity of bacterial groups notably in the SAR11 clade, one of the most common clades in the oceans (Giovannoni et al., 2005). They have also been identified in the alphaproteobacterial SAR116 clade (Oh et al., 2010; Grote et al., 2011) the gammaproteobacterial clade SAR92 (Stingl et al., 2007b), in Roseobacter clade and Bacteroidetes species (Gómez-Consarnau et al., 2007; González et al., 2008; Riedel et al., 2010; Yoshizawa et al., 2012) and in marine planktonic Archaea (Frigaard et al., 2006). Microbial rhodopsins are 
widespread and abundant in temperate and tropical marine waters. They have been detected in the Atlantic and Pacific oceans, in the Mediterranean and Red seas (Béjà et al., 2001; Venter et al., 2004; Rusch et al., 2007; Sabehi et al., 2007; Campbell et al., 2008). Some close homologs to PR are found in brackish, freshwater and sea ice environments (Atamna-Ismaeel et al., 2008; Koh et al., 2010).

PR photosystems have been detected in a large percentage of ocean surface-dwelling prokaryotes but estimates vary depending on the oceanic region and detection method. They accounted for up to $65 \%$ of total prokaryotes in the Sargasso Sea, $35 \%$ in the North Sea and 13\% in the Mediterranean Sea, and ranged from 7 to $57 \%$ in the North Atlantic Ocean (Venter et al., 2004; Sabehi et al., 2005; Rusch et al., 2007; Campbell et al., 2008; Riedel et al., 2010). However, there have been few quantitative assessments of PR gene abundance in marine environments, especially in high latitudes.

The Arctic Ocean is a largely land-locked basin with a cold, brackish upper mixed layer. The upper photic waters are separated from deeper waters by a strong halocline that is maintained by large river inputs and the annual formation and melting of sea ice (Aagaard et al., 1981). The physical isolation, perennially cold water temperatures, and extreme annual light cycle provide a unique marine habitat for microorganisms (Carmack and MacDonald, 2002). PR gene diversity has been reported in a few arctic coastal sites (Cottrell and Kirchman, 2009; Nguyen et al., 2015) but the abundance of PR-containing bacteria has not been examined at a large scale in a polar marine basin such as the western Arctic Ocean.

We examined the phylogenetic diversity and abundance of PR genes along a 3,000 km transect from the North East Pacific to the Arctic Ocean, which mainly focused on the Beaufort Sea and the Mackenzie shelf and estuary. Our objectives were to identify the major bacterial groups that actively expressed PR in the Arctic Ocean during summer, to assess their absolute abundance and to determine which environmental factors control their distribution. We expected that most PR-containing bacteria actively transcribe the PR gene during arctic summer and that the distribution of major PR types differed in open and coastal oceanic arctic waters in response to different environmental parameters.

\section{MATERIALS AND METHODS}

\section{Sampling and Oceanographic Parameters}

The MALINA cruise took place onboard the Canadian research icebreaker CCGS Amundsen during summer 2009 from Victoria (BC, Canada) to the Beaufort Sea (Leg 1b) and then throughout the Beaufort Sea (Leg 2b) (Supplementary Figure S1). Most of the stations sampled on the west-east transect in the Beaufort Sea (Leg 2b) were ice-free. However, surface waters of eastward offshore waters were still ice-covered. Surface seawater samples were collected with an acid-cleaned bucket during Leg $1 \mathrm{~b}$ and in the Mackenzie plume (stations 395, 398, 694, and 697) during Leg 2b. In the Beaufort Sea, seawater was collected from six depths (up to $150 \mathrm{~m}$ ) using Niskin bottles mounted on a CTD (conductivity temperature depth probe) rosette. The methods used to collect the ancillary data of temperature, salinity, $\mathrm{pH}$, dissolved oxygen, colored dissolved organic matter (cDOM), photosynthetically active radiation (PAR), inorganic and organic nutrients, and chlorophyll $a$ data are provided in the Supplementary Material. Bacterioplankton biomass for DNA and total RNA extraction was collected onboard as previously described (Boeuf et al., 2013).

\section{Diversity Analysis of PR Genes and Transcripts}

DNA was extracted as previously described (Marie et al., 2006) and concentrated using $100 \mathrm{kDa}$ Amicon Ultra centrifugal filter device (Millipore). Total RNA was extracted using the RNeasy Mini kit (Qiagen) as in Boeuf et al. (2013). ThermoScript RTPCR system (Invitrogen) was used for the reverse transcription of PR mRNA from total RNA samples. The cDNA synthesis was performed at $55^{\circ} \mathrm{C}$ using the $\mathrm{PR} 1-\mathrm{aR}$ primer as genespecific primer (Supplementary Table S1). PR genes were detected by PCR amplification with degenerate primers (Supplementary Table S1) using conditions described by Campbell et al. (2008). Primers pairs from Atamna-Ismaeel et al. (2008) targeting actinorhodopsin-like sequences were also used but did not yield positive PCR products. PR genes and transcript amplicons were cloned directly or after gel extraction using the TOPO4TA cloning kit (Invitrogen) according to the manufacturer's instructions. Recombinant clones were sequenced as in Boeuf et al. (2013).

The sequences were trimmed to remove any vector and primer sequences. DNA sequences were translated into amino acid sequences and aligned according to the tertiary structure of proteins using the E-INS-I strategy and BLOSUM62 substitution matrix from MAFFT (Katoh et al., 2009). The resulting protein alignment was back translated to nucleotide acid sequences using Geneious software (Drummond et al., 2012). A conservative value of $82 \%$ amino acid sequence similarity (Campbell et al., 2008) was chosen for clustering sequences into operational taxonomic units (OTUs) using MOTHUR (Schloss et al., 2009). Representative sequences (defined as the sequence with the minimum distance to all other sequences in the OTU) were obtained using MOTHUR. The coverage value (Mullins et al., 1995), the Shannon index, $H_{\text {Shannon }}$ (Shannon, 2001) and the bias-corrected richness-estimator, $S_{\text {Chaol }}$ (Chao et al., 2005) were calculated for each library (Supplementary Table S2).

A PR gene database containing about 2,000 aligned sequences of cultured species and environmental sequences retrieved from GenBank was constructed using Geneious (Drummond et al., 2012). A phylogenetic tree was constructed with entire protein sequences by Bayesian inference using MrBayes 3.0 (Ronquist and Huelsenbeck, 2003) with mixed models of amino acid substitution estimated by Markov chain Monte Carlo (MCMC) procedure. Four parallel MCMC chains of 1.5 million generations were run and trees were sampled every 100 generations. A consensus tree was constructed after the exclusion of 13,000 'burn-in' trees. The PR gene database and 
the consensus tree were imported into ARB software (Ludwig et al., 2004). Representative sequences of each OTU and short PR gene environmental sequences were aligned as above and added to the consensus Bayesian tree using the ADD_BY_PARSIMONY algorithm implemented in ARB. Non-informative taxa were removed from the final tree.

\section{Quantification of PR Gene Abundance}

Eight major PR-containing bacterial groups were targeted by $\mathrm{qPCR}$. When primers specific for these clades were not available in literature, they were designed using ARB (Supplementary Table S1). OTU3b (alphaproteobacterial "Arctic" group), OTU1 (alphaproteobacterial HOT2C01 cluster), OTU9 and OTU11 (gammaproteobacterial SAR92 clusters), OTU10 (gammaproteobacterial Glaciecola cluster) and a cluster of four Flavobacterium arctic isolates were targeted by $\mathrm{QPCR}$ to assess their distribution and absolute contribution to the arctic bacterial community. The abundance of SAR11 PR clade and of subcluster OTU3a (alphaproteobacterial "Arctic" group) were assessed by using primers sets designed by Campbell et al. (2008) and Cottrell and Kirchman (2009), respectively. The 16S rRNA genes for all bacteria and for SAR11 clade were quantified using primers (Supplementary Table S1) and conditions described by Suzuki et al. (2000, 2001). Plasmid clones from our Beaufort Sea PR and $16 \mathrm{~S}$ rRNA libraries were used as positive controls and in standard curves (10-fold dilution series) in the qPCR assays. Plasmid DNA was linearized with HindIII and quantified using the Picogreen assay (Invitrogen).

QPCR was performed in triplicate with $1 \mu l$ of environmental DNA normalized to $100 \mathrm{pg} \cdot \mu \mathrm{l}^{-1}$ or plasmid DNA solution in a total reaction volume of $10 \mu \mathrm{l}$ using the ABsolute QPCR SYBR Green/ROX Master Mix kit (Thermo Scientific). QPCR assays were performed using a Chromo4 Real-Time PCR Detection System and the Opticon Monitor software package (Bio-Rad) with the following thermal cycling conditions: $95^{\circ} \mathrm{C}$ for $15 \mathrm{~min}$, 45 cycles of denaturation at $95^{\circ} \mathrm{C}$ for $45 \mathrm{~s}$, primer annealing at the primer-specific temperature (Supplementary Table S1) for $45 \mathrm{~s}$ with fluorescence measurements after this step, and polymerase extension at $72^{\circ} \mathrm{C}$ for $15 \mathrm{~s}$. Melting curves were generated after each assay to check the specificity of the amplification by heating from 65 to $95^{\circ} \mathrm{C}$ at a rate of $0.1^{\circ} \mathrm{C} . \mathrm{s}^{-1}$ and taking fluorescence measurements every $5 \mathrm{~s}$. Only single peaks were observed in the dissociation curves for both the standards and samples, indicating specific amplification with each set of primers. Average amplification efficiencies were as follows: bacterial $16 \mathrm{~S} \mathrm{rDNA}=103.7 \%( \pm 0.9)$, SAR11 16S $\mathrm{rDNA}=95.3 \%( \pm 0.36)$, SAR11-PR $=95.6 \%( \pm 1.16)$, summer clade $($ OTU3a-PR $)=98.3 \%( \pm 1.39)$, OTU3b-PR $=104.3 \%$ $( \pm 2.81)$, OTU11-PR $=98.4 \%( \pm 0.98)$, OTU9-PR $=95.1 \%$ $( \pm 2.03)$, OTU1-PR $=95.9 \%( \pm 0.84)$, OTU10-PR $=101 \%$ $( \pm 3.05)$ and Flavobacterium-PR $=103.7 \%$.

No inhibition was detected when a known quantity of standard was added to DNA extracts (data not shown). In order to estimate the fraction of the bacterial community bearing each PR gene type, the estimates of PR gene abundance were normalized to $16 \mathrm{~S}$ rRNA gene abundance, assuming one PR gene copy and 1.9 $16 \mathrm{~S}$ rRNA copies per genome (Venter et al., 2004; Campbell et al.,
2008). The fraction of the SAR11 community bearing PR gene was assessed after normalization of SAR11 PR gene abundance to that of SAR11 16S rRNA gene, assuming one copy of both genes per genome in SAR11 cells. To estimate total abundances of PRcontaining bacteria, we summed the abundance estimates of the eight-targeted groups.

\section{Statistical Analyses}

All statistical analyses have been conducted using XLstat software (Addinsoft, France). Links between abundances and environmental variables were explored using Pearson's correlation tests. The similarity between clone libraries was assessed by a Bray-Curtis distance matrix calculated after resampling and was inferred with the UPGMA algorithm.

\section{Nucleotide Sequence Accession Numbers}

The environmental PR gene sequences obtained in this study are available in GenBank database under the accession numbers JX863105 to JX863220 (DNA sequences) and JX863221 to JX863333 (cDNA sequences).

\section{RESULTS}

\section{Community Composition and Diversity of PR Sequences}

Of a total of 617 PR gene sequences retrieved along the transect covering the North Pacific Ocean to the Beaufort Sea, 306 were obtained from DNA and 311 from cDNA libraries. 72 distinct OTUs were identified after clustering sequences at $82 \%$ amino acid sequence similarity (Campbell et al., 2008). Coverage estimates ( $>80 \%)$ and rarefaction curves (data not shown) indicated that most of the diversity was sampled at both offshore and shelf stations (Supplementary Table S2). This observation was confirmed by $\mathrm{S}_{\text {Chaol }}$ values (estimated numbers of expected OTUs), which agreed with the numbers of retrieved OTUs. The diversity of PR types, assessed with Shannon index, was generally higher in surface than in deeper waters with the highest diversity observed in the Mackenzie River mouth while the coverage index was low (Supplementary Table S2).

A majority of the sequences $(>72 \%, 18$ OTUs) were found in both DNA and cDNA libraries. A total of $16 \%$ of the sequences were only recovered in DNA libraries (34 OTUs) while $11 \%$ were restricted only to cDNA librairies (20 OTUs). A phylogenetic tree was constructed from all 72 OTUs identified in this study and from previous studies (Figure 1). Our phylogenetic analysis revealed that most PR sequences were associated with classes Gammaproteobacteria (20 OTUs, $\sim 46 \%$ of the sequences) and Alphaproteobacteria (16 OTUs, $43 \%$ of the sequences). Sequences affiliated with the Bacteroidetes accounted for an equivalent number of OTUs (18) but a lower proportion of sequences $(\sim 7 \%)$. Other OTUs $(\sim 4 \%$ of the sequences) were related to classes Betaproteobacteria or Deltaproteobacteria or remained unassigned. Hierarchical 


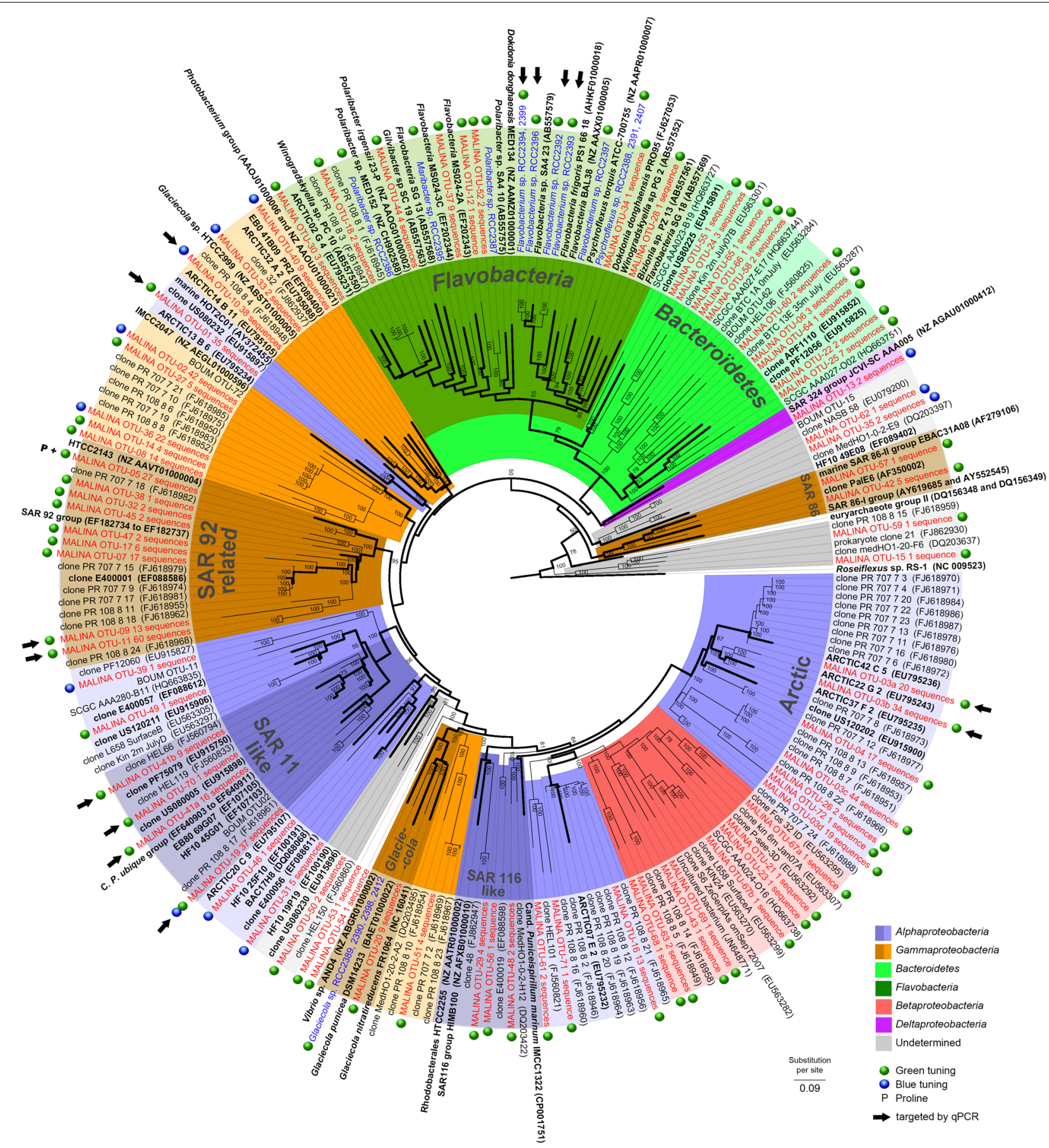

FIGURE 1 | Phylogenetic tree showing the relationships between PR gene sequences from MALINA environmental samples (in red) and isolates (in blue) (Supplementary Material), and from relatives retrieved in GenBank (in black). Blue and green dots show the predicted PR absorption of blue or green light as inferred from the amino acid sequence according to Man et al. (2003) (Supplementary text). P indicates PR variants with proline at position 105. Black arrows indicate OTUs targeted by qPCR assays. The tree is based on a bayesian tree to which short sequences were added by ARB_PARSIMONY. Initial bayesian tree is shown in bold lines. The numbers on nodes represent branch confidence values. The scale bar represents dissimilarity between amino acid positions.

clustering analysis of the PR community composition clearly separated surface and deep samples (Supplementary Figure S2). Alphaproteobacteria generally dominated in surface samples while Gammproteobacteria prevailed in deeper layers.
About half of the alphaproteobacterial PR clones (117 sequences) grouped exclusively with $\mathrm{PR}$ sequences from the Chukchi, Beaufort, and Bering Seas (Cottrell and Kirchman, 2009). This "Arctic group" contained OTU3a that corresponded 
to an "Arctic summer clade" revealed by Cottrell and Kirchman (2009). Sequences related to the SAR11 clade including Candidatus 'Pelagibacter ubique' (91-100\% similarity) contributed for $10 \%$ of $\mathrm{PR}$ clones, most of them retrieved from the RNA library. One of the largest alphaproteobacterial clades contained sequences closely related to the HOT2C01 fosmid gene, a PR type highly abundant the Sargasso Sea (Campbell et al., 2008).

Most gammaproteobacterial clones were closely related to Arctic sequences and belonged to novel OTUs. However, others including OTU9 and OTU11 (13 and 60 sequences) grouped with cultured representatives of the SAR92 group (Cho and Giovannoni, 2004; Stingl et al., 2007b; Oh et al., 2010). OTU10 (38 sequences) showed significant levels of similarity (>79\%) with the PR gene of Glaciecola sp. HTCC2999. Only a few clones were assigned to the gammaproteobacterial SAR86 group, an abundant uncultivated ubiquitous marine lineage (Sabehi et al., 2004; Dupont et al., 2012). About half of OTUs affiliated to Bacteroidetes belonged to the class Flavobacteria.

\section{Abundance and Distribution of Main PR Types}

Using the dataset of $\mathrm{PR}$ sequences retrieved from the Beaufort Sea, we designed qPCR primers to target six major groups of PR types namely the alphaproteobacterial OTU3b and OTU1, the SAR92-related OTU9 and -11, the Glaciecola-related OTU10 and a cluster of 4 isolates related to Flavobacterium frigoris (Boeuf, 2013). Primers sets designed by Campbell et al. (2008) and Cottrell and Kirchman (2009) were also used to investigate the abundance of SAR11 PR and OTU3a clades, respectively. The design of universally conserved qPCR primers able to capture most PR types is impossible. Therefore, to estimate total abundances of PR-containing bacteria, we added together the abundance estimates of all eight tested microbial groups containing PR genes (Table 1). In the Beaufort Sea (Table 1), the total PR relative abundances ranged from below 1 to $45 \%$ with a mean contribution of about $15 \%$ of total bacteria.

Water categories as defined in Boeuf et al. (2013) using temperature and salinity profiles displayed close mean PR contributions with the highest proportions obtained in offshore waters. Absolute abundances of PR types did not match the relative abundances in clone libraries. Alphaproteobacterial PR types ( $>95 \%$ of the total PR groups) dominated in all water types. Although, weak variations in their mean relative abundance were obtained in the different water categories, distinct biogeographical patterns occurred at the clade level.

The SAR11 PR-containing bacteria prevailed in all water types of the Beaufort Sea and their mean surface contributions doubled from the river plume to offshore waters. Highest surface contributions were recorded near the Amundsen Gulf and in the central Beaufort Sea (Supplementary Figure S3). In most shelf and offshore stations, SAR11 PR abundances increased with depth and peaked (up to 35\%) below or above the chlorophyll maximum (Supplementary Figure S4). The highest SAR11 PR contributions (>30\%) were obtained offshore at $50 \mathrm{~m}$ depth. The second most abundant PR type,
OTU 3a, had higher contributions in surface that increased from the river plume to offshore waters (Supplementary Figure S3). The OTU3b PR type showed the same distribution pattern but was less abundant. Both latter clades decreased sharply with depth (Supplementary Figure S4). The HOT2C01related OTU 1 displayed an opposite distribution pattern, decreasing significantly from the river plume to offshore waters (Supplementary Figure S3). Surprisingly, contributions of gammaproteobacterial PR groups were generally low, ranging from less than 0.1 to $3.4 \%$ (Supplementary Figure S3). Their highest contributions were obtained in shelf surface (OTU9) and deeper waters (OTU11). Flavobacterium PR type was generally poorly detected in the Beaufort Sea where its highest abundances were obtained in offshore surface samples (Supplementary Figure S3). General trends observed in surface waters of the Beaufort Sea were confirmed along the North Pacific Ocean-Beaufort Sea transect (Supplementary Table S3). However, high relative abundances of OTU3a and Flavobacterium were obtained in samples of the Chukchi Sea.

\section{Assessing the Contribution of the PR Gene in the SAR11 Clade}

The SAR11 PR types were the major component (63\%) of the PR-containing community in the Beaufort Sea (Tables 1 and 2). To better understand this contribution, we quantified the $16 \mathrm{~S}$ rRNA gene abundance of the SAR11 clade by qPCR (Table 2). SAR11 represented about the third $(32 \% \pm 21 \%)$ of the total bacterial community with contributions twice higher in offshore waters than in coastal samples. In all water categories, about a third $(32 \% \pm 17 \%)$ of the SAR11 community harbored a PR gene (Table 2), but these proportions were highly variable among samples (from $<5$ to $90 \%$ ).

\section{Links between Main PR Types and Environmental Parameters}

Relative abundances of most PR types and total prokaryotic abundances displayed distinct relationships with environmental variables (Table 3). Most inorganic nutrients and $\mathrm{CDOM}$, that showed a strong inshore-offshore gradients along the MacKenzie river plume (Matsuoka et al., 2012; Tremblay et al., 2014) covariated (data not shown) and were negatively correlated with most PR types relative abundances. Such results reflect that high PR concentrations were linked to the nutrient-depleted polar mixed layer. Contributions of the SAR11 PR type followed this general trend and also showed a significant positive correlation with oxygen concentrations $(r=0.334, p<0.005)$. SAR92related OTU11 was the most notable exception to these prevailing relationships. In contrast to all other PR types, OTU11 abundance increased significantly with salinity, nutrients and chlorophyll concentrations, but decreased with temperature. Four PR types (OTU3a, OTU3b, OTU1 and Flavobacterium) decreased significantly with depth. In contrast to the three other types, OTU3a increased significantly with temperature $(r=0.366$, $p<0.005)$ and light $(r=0.266, p<0.05)$, indicating its preference for coastal epipelagic waters. An inverse relationship was found between relative abundance of Flavobacterium PR 


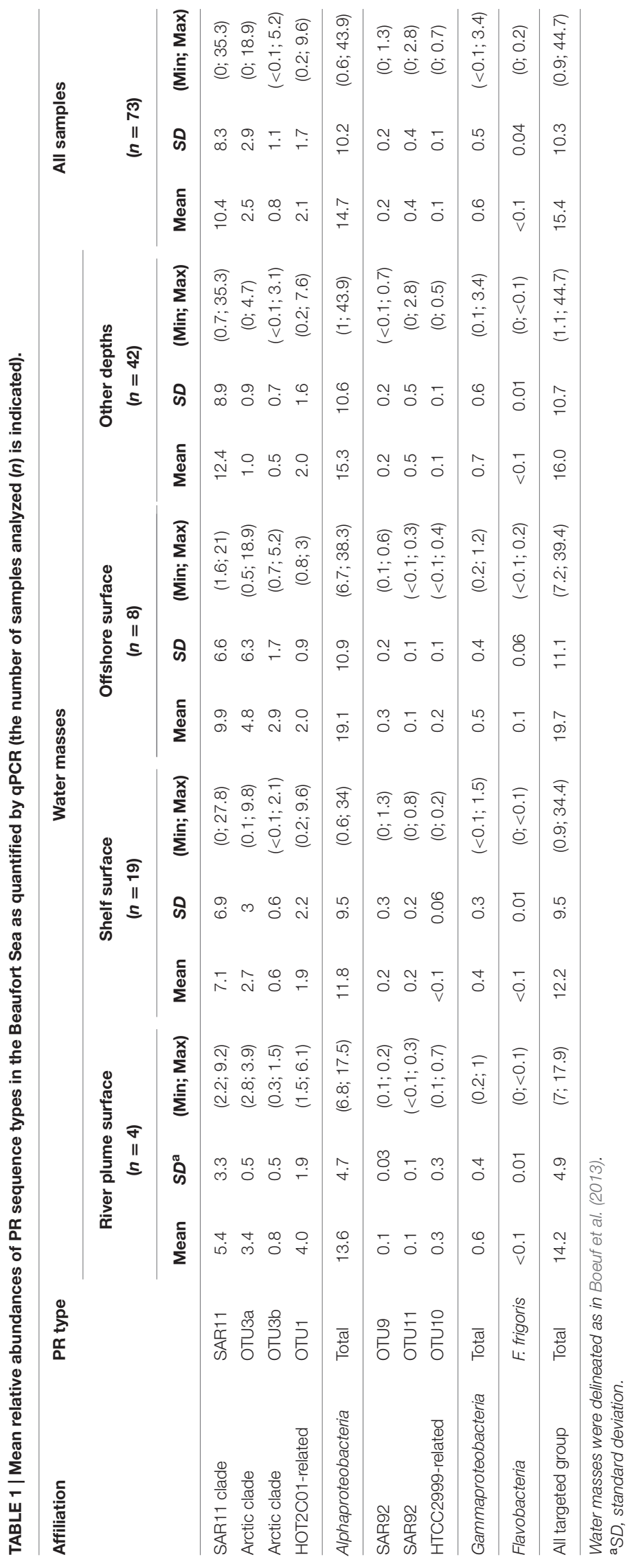


type and salinity $(r=-0.302, p<0.05)$, consistent with the dominance of Flavobacteria in bacterial communities of sea-ice and melting water (Staley and Gosink, 1999; Brinkmeyer et al., 2003).

\section{DISCUSSION}

Our estimates of PR gene diversity (number of OTUs, $\mathrm{S}_{\text {Chao1 }}$ and $\left.\mathrm{H}_{\text {Shannon }}\right)$ in the Beaufort Sea waters are similar to that reported in temperate environments (Lami et al., 2009; Riedel et al., 2010). This indicates that low-temperature environments also harbor substantial genetic diversity of PR genes. One half of the PRs retrieved in this study was closely related $(>82 \%$ amino acid similarity) with sequences widely distributed in lowlatitude marine waters. The other half matched with Arctic sequences or belonged to novel OTUs, suggesting that they are endemic. This observation contrasts with previous studies of puf $\mathrm{M}$ and 16S rRNA gene diversity that revealed larger sets of sequences restricted to Arctic waters (Cottrell and Kirchman, 2009; Ghiglione et al., 2012; Boeuf et al., 2013).

\section{PR-Based Phototrophy Is the Main Prokaryotic Phototrophic Process in the Arctic Ocean}

We observed a substantial overlap between DNA- and cDNAderived libraries, indicating that a large fraction of the summer PR community actively expressed proteorhodopsin in the Beaufort Sea euphotic waters at the time of sampling. We chose to quantify PR types representing the largest active OTUs by qPCR. Although, the targeted OTUs covered more than half of the recovered sequences, our total numbers are inevitably incomplete. Therefore, they have to be viewed as lower estimates of the actual contribution of PR bacteria to the total bacterial community. These estimates remain lower than those reported from the analysis of the GOS metagenome datasets (about 65\%) (Venter et al., 2004; Rusch et al., 2007). The mean abundance values were also lower than previous $\mathrm{qPCR}$ analyses that found a PR gene in half of the bacteria in the Sargasso Sea, 23\% in the North Atlantic (Campbell et al., 2008), and about $34 \%$ in the North Sea (Riedel et al., 2010). However, these sets of data are not easily comparable because the coverage of qPCR primer sets is different between these studies.

Here, we observed that the variability of the measured relative abundances was remarkably high at the PR type level, probably reflecting a heterogeneous distribution of PR bacteria in Arctic waters. This heterogeneity was especially exemplified by SAR11 PR type whose variable proportions were locally higher (up to $45 \%$ of the bacterial community) than that found in lower latitude regions (Campbell et al., 2008; Riedel et al., 2010).

Our study demonstrates that contributions of PR-containing organisms outclass those of other phototrophic prokaryotes (cyanobacteria and aerobic anoxygenic phototrophs (AAPs)). Indeed, abundance of cyanobacteria is typically low in marine polar waters (Li et al., 2009) and they were completely absent in Arctic waters of the Chukchi and Beaufort Seas during the Malina cruise (Balzano et al., 2012) as observed previously (Li, 


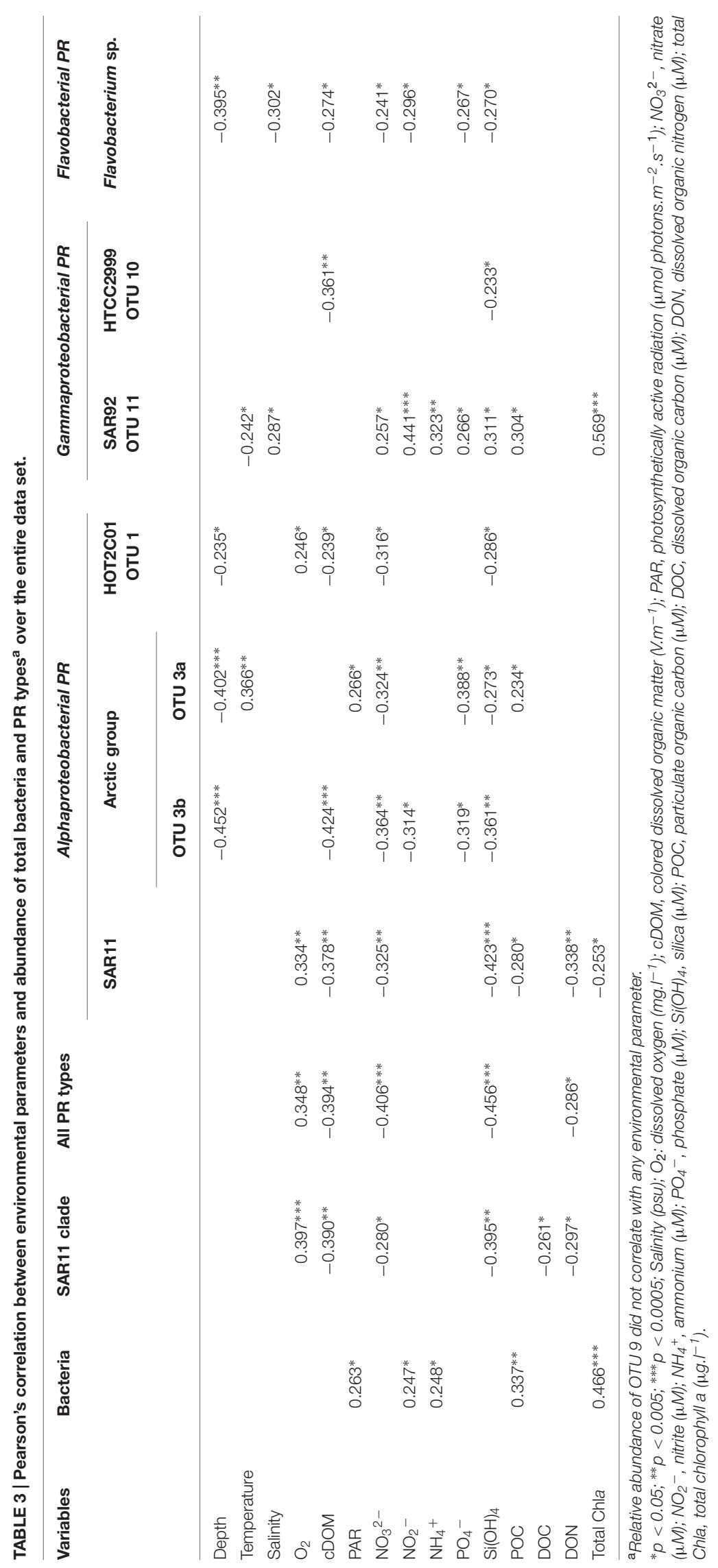


1998). Recently, we reported that AAP bacterial contributions decreased strongly from the Mackenzie River to the open ocean, with a mean of $7 \%$ in the Mackenzie mouth, $1 \%$ inshore, and $0.1 \%$ offshore (Boeuf et al., 2013). Similar proportions (14\%) of AAPs and PR-containing bacteria were only obtained in some surface water samples of the Mackenzie plume. We can therefore assume that $\mathrm{PR}$ phototrophy is the main prokaryotic phototrophic process in the Beaufort Sea.

\section{Alphaproteobacterial PR Types are Prevalent in Arctic Waters}

According to the qPCR abundance estimates, alphaproteobacterial PR genes represented about $95 \%$ of the PR community in all sampled waters. This result could appear surprising because estimates of gene abundance based on frequencies in clone libraries were almost similar for alphaproteobacterial and gammaproteobacterial sequences. By inspecting the sequence templates of the PCR primer set in the limited number of strains whose genome is available yet, we found that preferential amplification of gammaproteobacterial PR sequences may explain these discrepancies. However, although Gammaproteobacteria were overestimated in our PR clone libraries, $16 \mathrm{~S}$ rRNA pyrosequencing analyses demonstrated that they represent one of the two most abundant bacterial groups in the Arctic Ocean, accounting for about $20-30 \%$ of the total bacterial community (Kirchman et al., 2010; Comeau et al., 2011).

Although SAR11 PR type was moderately abundant in clone libraries, qPCR estimates revealed it as the dominant clade in coastal and oceanic waters of the Beaufort Sea. Interestingly, its proportions in Arctic oceanic waters were close to those measured in the North Atlantic (Campbell et al., 2008) and higher than those found in the North Sea (Riedel et al., 2010), two marine environments where other alphaproteobacterial PR genes dominated. In most samples other than surface, we found that SAR11 PR type made up at least for $70 \%$ of the PR arctic community, revealing a remarkable adaptability to summer arctic conditions.

OTU3a, the second most abundant PR type, was previously reported in coastal waters of the Chukchi and western Beaufort Seas (Cottrell and Kirchman, 2009). Together with our data, the latter study suggests that this clade is restricted to high latitudes. Our quantitative estimates indicated that it made up similar proportions than of SAR11 PR type in several stations in the coastal Beaufort Sea and even outgrew it in the productive waters of the Chukchi Sea. Little is known about this clade but our results suggest that it could transiently represent a prominent and active component of the bacterioplankton in surface Arctic waters.

\section{Proteorhodopsin in the Arctic SAR11 Community}

To evaluate PR gene contribution within the SAR11 community, we assessed the relative abundance of SAR11 16S rRNA gene copies by qPCR. Our estimates of SAR11 contributions (about 30\% of the total prokaryotes) were in agreement with
CARD-FISH experiments (Malmström et al., 2007; AlonsoSáez et al., 2008) and 454 sequencing analysis (Comeau et al., 2011) conducted in Arctic waters. Based on our average estimates obtained by qPCR, only about a third of SAR11 bacteria contained a PR gene. However, proportions of SAR11 containing the PR gene in the SAR11 community were highly heterogeneous, ranging from 5 to $90 \%$ according locations. This result contrasts with previous data from field experiments that found proteorhodopsin in about $80 \%$ of the SAR 11 community (Campbell et al., 2008) and from comparative analysis of seven genomes from different SAR11 subclades that revealed one PR gene per genome (Grote et al., 2012). These data suggest that PR phototrophy is likely to be present in only some SAR11 populations and could be in line with the observation of a differential distribution patterns of SAR11 subclades or ecotypes (Field, 1997; Brown and Fuhrman, 2005), which follows a strong zonation according latitude or depth (Brown et al., 2012). Interestingly, the dominant SAR11 phylotype (P1a) in polar waters contained numerous PR-containing strains (Brown et al., 2012). In our study, the fact that the PR gene was not homogeneously found in the SAR11 community could suggest a distribution according ecotypes rather than phylotypes or at finer phylogenetic levels than previously defined.

\section{Contextual Parameters Explaining PR Community Structure}

Studies of PR gene expression in natural waters as well as in light-dark incubations of model bacteria in culture demonstrated that the PR gene can be strongly upregulated by light (Lami et al., 2009) and by nutrient limitation (Akram et al., 2013). Environmental conditions in the Arctic Ocean range from constant light and nutrient depletion during summer to complete darkness and sea ice during winter. In the Beaufort Sea, the abundance of most PR types increased with decreasing nutrient and $\mathrm{CDOM}$ concentrations while the abundance of only one PR type was positively correlated with light. The pelagic Beaufort Sea is oligotrophic during summer as a result of the strong vertical stratification caused by Mackenzie River inputs and sea-ice melting (Carmack and MacDonald, 2002). These lownutrient conditions prevailed during the Malina cruise where low surface nitrate concentrations limiting heterotrophic bacterial growth were observed (Ortega-Retuerta et al., 2012). Our data suggest that in the arctic conditions, adaptation to nutrient limitation rather than light availability would regulate the abundance and distribution of PR bacteria. This is consistent with the presence of PR-containing bacteria in both summer and winter (Cottrell and Kirchman, 2009; Nguyen et al., 2015) and their activity in the ice at low light intensities (Koh et al., 2010).

Summer oligotrophic conditions as inducing factors of PR gene expression would be also consistent with the high proportions of active PR bacteria we found in the Beaufort Sea. It is conceivable that energy gained by phototrophy may confer to PR bacteria the capacity to better face the low-nutrient conditions. This hypothesis is supported by the observation that some PR bacteria better survive low-nutrient conditions (GómezConsarnau et al., 2010; Steindler et al., 2011). We found that 
the active PR community was dominated by SAR11 members, whose abundance was negatively correlated with Chl $a$, POC and DON concentrations. These data reinforce the idea that SAR11 is well-adapted to nutrient-limited oligotrophic marine environments (Malmström et al., 2005; Lauro et al., 2009). However, the dominance and activity of SAR11 PR type within the large environmental gradients of the Beaufort Sea indicate that their unique metabolic capacities allow them to thrive well in a wide range of trophic conditions, challenging the notion that these oligotrophs are adapted for the efficient use of dissolved substrates (Giovannoni et al., 2005).

By contrast to other PR types, the relative abundance of SAR92-related PR (OTU11) increased along the nutrient, cDOM and Chla concentrations. Such an observation indicates that these organisms are competitive at high organic matter and inorganic nutrient concentrations supplied during the highdischarge period of the MacKenzie River. This idea is consistent with the observation that SAR92 clade members are responsive to phytoplankton blooms induced by inorganic nutrient enrichment in microcosm experiments (Pinhassi et al., 2005) and aided the isolation of SAR 92 strains from the nutrient-rich upwelling off the Oregon coast (Stingl et al., 2007a). An active role in the breakdown of algae-derived compounds has been recently suggested for these organisms (Teeling et al., 2012). Although the growth of HTCC2207, the first cultivated SAR92 strain, was found to be limited by the amount of available carbon (Stingl et al., 2007a), SAR92 members may be adapted to more nutrientrich patches in the natural environment and responds more readily to phytoplankton bloom dynamics. First physiological analyses revealed that HTCC2207 showed no responses to light (Stingl et al., 2007a) and the benefit of PR phototrophy for this organism has not been identified yet.

In summer, ice melt-induced stratification of the water column, local and transient phytoplankton blooms as well as aggregation of particulate organic matter contribute to the seascape variability in the Beaufort Sea heavily impacted by the Mackenzie River and smaller rivers. Moreover, numerous biotic processes result in patchy resource distributions. The different responses of PR types to environmental parameters mirror the strong spatial variability of their abundance. Together, our results suggest that PR phototrophy may help microorganisms thriving in extreme arctic conditions and favor energy production to exploit this heterogeneity during the Arctic summer.

\section{CONCLUSION}

This diversity and qPCR analyses of PR sequence genes in marine waters of the Arctic Ocean generated novel

\section{REFERENCES}

Aagaard, K., Coachman, L., and Carmack, E. (1981). On the halocline of the Arctic Ocean. Deep Sea Res. 28, 529-545. doi: 10.1016/0198-0149(81)90115-1

Akram, N., Palovaara, J., Forsberg, J., Lindh, M. V., Milton, D. L., Luo, H., et al. (2013). Regulation of proteorhodopsin gene expression by nutrient limitation insights into the composition and spatial distribution of PR-containing bacteria. The PR amplicons showed great spatial divergence in composition, and were frequently dominated by genes related to taxonomically diverse organisms, most of them being expressed at the time of sampling. Although, the abundance of PR-containing bacteria is highly variable between locations, depths and taxonomic clades, our results indicate that $\mathrm{PR}$ phototrophy may be a significant process contributing to the carbon cycle in the Arctic Ocean.

The ecological mechanisms that underlie this variability and the energetic benefits of PR-based phototrophy in the world's oceans remains to be elucidated.

\section{AUTHOR CONTRIBUTIONS}

All authors were substantially involved in the data acquisition and/or data analyses. DB and CJ wrote the first draft of the manuscript and all authors contributed substantially to revisions.

\section{ACKNOWLEDGMENTS}

This study was conducted as part of the Malina Scientific Program funded by ANR (Agence Nationale de la Recherche), INSU-CNRS (Institut National des Sciences de l'Univers Centre National de la Recherche Scientifique), CNES (Centre National d'Etudes Spatiales) and ESA (European Space Agency). We thank all participants to the MALINA cruises for their help, especially M. Babin who coordinated the project, K. Lévesque for the logistics, and all CCGS Amundsen crew members. We warmly thank D. Doxaran, P. Raimbault, N. Garcia, and J. Ras for providing ancillary data. We are grateful to M. Perennou and G. Tanguy (Biogenouest Sequencing Platform-FR2424-Station Biologique) for help with sequencing. This work was supported by the ANR RHOMEO (ANR 11 BSV7 021 02) and the European Union program MicroB3 (UE-contract-287589). DB was supported by a grant from the French Ministry of Higher Education and Research.

\section{SUPPLEMENTARY MATERIAL}

The Supplementary Material for this article can be found online at: http://journal.frontiersin.org/article/10.3389/fmicb. 2016.01584

in the marine bacterium Vibrio sp. AND4. Environ. Microbiol. 15, 1400-1415. doi: 10.1111/1462-2920.12085

Alonso-Sáez, L., Sánchez, O., Gasol, J. M., Balagué, V., and Pedrós-Alio, C. (2008). Winter-to-summer changes in the composition and single-cell activity of near-surface arctic prokaryotes. Environ. Microbiol. 10, 2444-2454. doi: $10.1111 /$ j.1462-2920.2008.01674.x 
Atamna-Ismaeel, N., Sabehi, G., Sharon, I., Witzel, K. P., Labrenz, M., Jürgens, K., et al. (2008). Widespread distribution of proteorhodopsins in freshwater and brackish ecosystems. ISME J. 2, 656-662. doi: 10.1038/ismej. 2008.27

Balzano, S., Marie, D., Gourvil, P., and Vaulot, D. (2012). Composition of the summer photosynthetic pico and nanoplankton communities in the Beaufort Sea assessed by T-RFLP and sequences of the 18S rRNA gene from flow cytometry sorted samples. ISME J. 6, 1480-1498. doi: 10.1038/ismej.2011.213

Béjà, O., Aravind, L., Koonin, E. V., Suzuki, M. T., Hadd, A., Nguyen, L. P., et al. (2000). Bacterial rhodopsin: evidence for a new type of phototrophy in the sea. Science 289, 1902-1906. doi: 10.1126/science.289.5486.1902

Béjà, O., Spudich, E. N., Spudich, J. L., Leclerc, M., and DeLong, E. F. (2001). Proteorhodopsin phototrophy in the ocean. Nature 411, 786-789. doi: $10.1038 / 35081051$

Boeuf, D. (2013). Ecological Significance of Photoheterotrophic Bacteria in the Arctic Ocean (Importance Écologique des Bactéries Photohétérotrophes dans l'Océan Arctique). Ph.D. thesis, Universities Pierre and Marie Curie University, Paris.

Boeuf, D., Cottrell, M. T., Kirchman, D. L., Lebaron, P., and Jeanthon, C. (2013). Summer community structure of aerobic anoxygenic phototrophic bacteria in the western Arctic Ocean. FEMS Microbiol. Ecol. 85, 417-432. doi: 10.1111/1574-6941.12130

Brinkmeyer, R., Knittel, K., Jurgens, J., Weyland, H., Amann, R., and Helmke, E. (2003). Diversity and structure of bacterial communities in Arctic versus Antarctic pack ice. Appl. Environ. Microbiol. 69, 6610-6619. doi: 10.1128/AEM.69.11.6610-6619.2003

Brown, M. V., and Fuhrman, J. A. (2005). Marine bacterial microdiversity as revealed by internal transcribed spacer analysis. Aquat. Microb. Ecol. 41, 15-23. doi: 10.3354/ame041015

Brown, M. V., Lauro, F. M., DeMaere, M. Z., Muir, L., Wilkins, D., Thomas, T., et al. (2012). Global biogeography of SAR11 marine bacteria. Mol. Syst. Biol 8:595. doi: $10.1038 / \mathrm{msb} .2012 .28$

Campbell, B. J., Waidner, L. A., Cottrell, M. T., and Kirchman, D. L. (2008). Abundant proteorhodopsin genes in the North Atlantic Ocean. Environ. Microbiol. 10, 99-109. doi: 10.1111/j.1462-2920.2007.01436.x

Carmack, E. C., and MacDonald, R. W. (2002). Oceanography of the Canadian Shelf of the Beaufort Sea: a setting for marine life. Arctic 55(Suppl. 1), 29-45. doi: 10.14430/arctic733

Chao, A., Chazdon, R. L., Colwell, R. K., and Shen, T. J. (2005). A new statistical approach for assessing similarity of species composition with incidence and abundance data. Ecol. Lett. 8, 148-159. doi: 10.1111/j.1461-0248.2004.00707.x

Cho, J. C., and Giovannoni, S. J. (2004). Cultivation and growth characteristics of a diverse group of oligotrophic marine Gammaproteobacteria. Appl. Environ. Microbiol. 70, 432-440. doi: 10.1128/AEM.70.1.432-440.2004

Comeau, A. M., Li, W. K. W., Tremblay, J. É., Carmack, E. C., and Lovejoy, C. (2011). Arctic Ocean microbial community structure before and after the 2007 record sea ice minimum. PLoS ONE 6:e27492. doi: 10.1371/journal.pone.0027492

Cottrell, M. T., and Kirchman, D. L. (2009). Photoheterotrophic microbes in the Arctic Ocean in summer and winter. Appl. Environ. Microbiol. 75, 4958-4966. doi: 10.1128/AEM.00117-09

Drummond, A. J., Ashton, B., Buxton, S., Cheung, M., Cooper, A., Duran, C., et al. (2012). Geneious v5.6. Available at: http://www.geneious.com

Dupont, C. L., Rusch, D. B., Yooseph, S., Lombardo, M.-J., Alexander Richter, R., Valas, R., et al. (2012). Genomic insights to SAR86, an abundant and uncultivated marine bacterial lineage. ISME J. 6, 1186-1199. doi: 10.1038/ismej.2011.189

Field, K. G. (1997). Diversity and depth-specific distribution of SAR11 cluster rRNA genes from marine planktonic bacteria. Appl. Environ. Microbiol. 63, $63-70$.

Frigaard, N. U., Martinez, A., Mincer, T. J., and DeLong, E. F. (2006). Proteorhodopsin lateral gene transfer between marine planktonic Bacteria and Archaea. Nature 439, 847-850. doi: 10.1038/nature04435

Fuhrman, J. A., Schwalbach, M. S., and Stingl, U. (2008). Proteorhodopsins: an array of physiological roles? Nat. Rev. Microbiol. 6, 488-494. doi: 10.1038/nrmicro1893

Ghiglione, J. F., Galand, P. E., Pommier, T., Pedrós-Alió, C., Maas, E. W., Bakker, K., et al. (2012). Pole-to-pole biogeography of surface and deep marine bacterial communities. Proc. Natl. Acad. Sci. U.S.A. 109, 17633-17638. doi: 10.1073/pnas.1208160109

Giovannoni, S. J., Bibbs, L., Cho, J. C., Stapels, M. D., Desiderio, R., Vergin, K. L., et al. (2005). Proteorhodopsin in the ubiquitous marine bacterium SAR11. Nature 438, 82-85. doi: 10.1038/nature04032

Gómez-Consarnau, L., Akram, N., Lindell, K., Pedersen, A., Neutze, R., Milton, D. L., et al. (2010). Proteorhodopsin phototrophy promotes survival of marine bacteria during starvation. PLoS Biol. 8:e1000358. doi: 10.1371/journal.pbio. 1000358

Gómez-Consarnau, L., González, J. M., Coll-Lladó, M., Gourdon, P., Pascher, T., Neutze, R., et al. (2007). Light stimulates growth of proteorhodopsin-containing marine Flavobacteria. Nature 445, 210-213. doi: 10.1038/nature05381

González, J. M., Fernández-Gómez, B., Fernàndez-Guerra, A., GómezConsarnau, L., Sánchez, O., Coll-Lladó, M., et al. (2008). Genome analysis of the proteorhodopsin-containing marine bacterium Polaribacter sp. MED152 (Flavobacteria). Proc. Natl. Acad. Sci. U.S.A. 105, 8724-8729. doi: 10.1073/pnas.0712027105

Grote, J., Bayindirli, C., Bergauer, K., de Moraes, P. C., Chen, H., D’Ambrosio, L., et al. (2011). Draft genome sequence of strain HIMB100, a cultured representative of the SAR116 clade of marine Alphaproteobacteria. Stand. Genomic Sci. 5, 269-278. doi: 10.4056/sigs.1854551

Grote, J., Thrash, J. C., Huggett, M. J., Landry, Z. C., Carini, P., Giovannoni, S. J., et al. (2012). Streamlining and core genome conservation among highly divergent members of the SAR11 clade. MBio 3, e00252-12. doi: 10.1128/mBio.00252-12

Jung, K. H., Trivedi, V. D., and Spudich, J. L. (2003). Demonstration of a sensory rhodopsin in eubacteria. Mol. Microbiol. 47, 1513-1522. doi: 10.1046/j.13652958.2003.03395.x

Katoh, K., Asimenos, G., and Toh, H. (2009). Multiple alignment of DNA sequences with MAFFT. Methods Mol. Biol. 537, 39-64. doi: 10.1007/978-159745-251-9_3

Kirchman, D. L., Cottrell, M. T., and Lovejoy, C. (2010). The structure of bacterial communities in the western Arctic Ocean as revealed by pyrosequencing of 16S rRNA genes. Environ. Microbiol. 12, 1132-1143. doi: 10.1111/j.14622920.2010.02154.X

Koh, E. Y., Atamna-Ismaeel, N., Martin, A., Cowie, R. O. M., Béjà, O., Davy, S. K., et al. (2010). Proteorhodopsin-bearing bacteria in Antarctic sea ice. Appl. Environ. Microbiol. 76, 5918-5925. doi: 10.1128/AEM.00562-10

Lami, R., Cottrell, M. T., Campbell, B. J., and Kirchman, D. L. (2009). Lightdependent growth and proteorhodopsin expression by Flavobacteria and SAR11 in experiments with Delaware coastal waters. Environ. Microbiol. 11, 3201-3209. doi: 10.1111/j.1462-2920.2009.02028.x

Lauro, F. M., McDougald, D., Thomas, T., Williams, T. J., Egan, S., Rice, S., et al. (2009). The genomic basis of trophic strategy in marine bacteria. Proc. Natl. Acad. Sci. U.S.A. 106, 15527-15533. doi: 10.1073/pnas.0903507106

Li, W. (1998). Annual average abundance of heterotrophic bacteria and Synechococcus in surface ocean waters. Limnol. Oceanogr. 43, 1746-1753. doi: 10.4319/lo.1998.43.7.1746

Li, W. K. W., McLaughlin, F. A., Lovejoy, C., and Carmack, E. C. (2009). Smallest algae thrive as the Arctic ocean freshens. Science 326, 539-539. doi: $10.1126 /$ science. 1179798

Ludwig, W., Strunk, O., Westram, R., Richter, L., and Meier, H. (2004). ARB: a software environment for sequence data. Nucleic Acids Res. 32, 1363-1371. doi: $10.1093 / \mathrm{nar} / \mathrm{gkh} 293$

Malmström, R. R., Cottrell, M. T., Elifantz, H., and Kirchman, D. L. (2005). Biomass production and assimilation of dissolved organic matter by SAR11 bacteria in the Northwest Atlantic Ocean. Appl. Environ. Microbiol. 71, 2979-2986. doi: 10.1128/AEM.71.6.2979-2986.2005

Malmström, R. R., Straza, T. R. A., Cottrell, M. T., and Kirchman, D. L. (2007). Diversity, abundance, and biomass production of bacterial groups in the western Arctic Ocean. Aquat. Microb. Ecol. 47, 45-55. doi: 10.3354/ ame 047045

Man, D., Wang, W., Sabehi, G., Aravind, L., Post, A. F., Massana, R., et al. (2003). Diversification and spectral tuning in marine proteorhodopsins. EMBO J. 22, 1725-1731. doi: 10.1093/emboj/cdg183

Marie, D., Zhu, F., Balagué, V., Ras, J., and Vaulot, D. (2006). Eukaryotic picoplankton communities of the Mediterranean Sea in summer assessed by 
molecular approaches (DGGE, TTGE, QPCR). FEMS Microbiol. Ecol. 55, 403415. doi: 10.1111/j.1574-6941.2005.00058.x

Matsuoka, A., Bricaud, A., Benner, R., Para, J., Sempéré, R., Prieur, L., et al. (2012). Tracing the transport of colored dissolved organic matter in water masses of the Southern Beaufort Sea: relationship with hydrographic characteristics. Biogeosciences 9, 925-940. doi: 10.5194/bg-9-925-2012

Mullins, T. D., Britschgi, T. B., Krest, R. L., and Giovannoni, S. J. (1995). Genetic comparisons reveal the same unknown bacterial lineages in Atlantic and Pacific bacterioplankton communities. Limnol. Oceanogr. 40, 148-158. doi: 10.4319/lo.1995.40.1.0148

Nguyen, D., Maranger, R., Balague, V., Coll-Llado, M., Lovejoy, C., and PedrosAlio, C. (2015). Winter diversity and expression of proteorhodopsin genes in a polar ocean. ISME J. 9, 1835-1845. doi: 10.1038/ismej.2015.1

Oh, H.-M., Kwon, K. K., Kang, I., Kang, S. G., Lee, J.-H., Kim, S.-J., et al. (2010). Complete genome sequence of "Candidatus Puniceispirillum marinum" IMCC1322, a representative of the SAR116 clade in the Alphaproteobacteria. J. Bacteriol. 192, 3240-3241. doi: 10.1128/JB.00347-10

Ortega-Retuerta, E., Jeffrey, W., Ghiglione, J., and Joux, F. (2012). Evidence of heterotrophic prokaryotic activity limitation by nitrogen in the Western Arctic Ocean during summer. Polar Biol. 35, 785-794. doi: 10.1007/s00300-0111109-8

Pinhassi, J., Simó, R., González, J. M., Vila, M., Alonso-Sáez, L., Kiene, R. P., et al. (2005). Dimethylsulfoniopropionate turnover is linked to the composition and dynamics of the bacterioplankton assemblage during a microcosm phytoplankton bloom. Appl. Environ. Microbiol. 71, 7650-7660. doi: 10.1128/aem.71.12.7650-7660.2005

Riedel, T., Tomasch, J., Buchholz, I., Jacobs, J., Kollenberg, M., Gerdts, G., et al. (2010). Constitutive expression of the proteorhodopsin gene by a Flavobacterium strain representative of the proteorhodopsin-producing microbial community in the North Sea. Appl. Environ. Microbiol. 76, 31873197. doi: 10.1128/AEM.02971-09

Ronquist, F., and Huelsenbeck, J. P. (2003). MrBayes 3: bayesian phylogenetic inference under mixed models. Bioinformatics 19, 1572-1574. doi: 10.1093/bioinformatics/btg180

Rusch, D. B., Halpern, A. L., Sutton, G., Heidelberg, K., Williamson, S., and Yooseph, S. (2007). The sorcerer II global ocean sampling expedition: northwest Atlantic through eastern tropical Pacific. PLoS Biol. 5:e77. doi: 10.1371/journal.pbio.0050077

Sabehi, G., Béjà, O., Suzuki, M. T., Preston, C. M., and DeLong, E. F. (2004). Different SAR86 subgroups harbour divergent proteorhodopsins. Environ. Microbiol. 6, 903-910. doi: 10.1111/j.1462-2920.2004.00676.x

Sabehi, G., Kirkup, B. C., Rozenberg, M., Stambler, N., Polz, M. F., and Béjà, O. (2007). Adaptation and spectral tuning in divergent marine proteorhodopsins from the eastern Mediterranean and the Sargasso Seas. ISME J. 1, 48-55. doi: 10.1038/ismej.2007.10

Sabehi, G., Loy, A., Jung, K.-H., Partha, R., Spudich, J. L., Isaacson, T., et al. (2005). New insights into metabolic properties of marine bacteria encoding proteorhodopsins. PLoS Biol. 3:e273. doi: 10.1371/journal.pbio.0030273

Schloss, P. D., Westcott, S. L., Ryabin, T., Hall, J. R., Hartmann, M., Hollister, E. B., et al. (2009). Introducing mothur: open-source, platform-independent, community-supported software for describing and comparing microbial communities. Appl. Environ. Microbiol. 75, 7537-7541. doi: 10.1128/aem. 01541-09
Shannon, C. E. (2001). A mathematical theory of communication. ACM Sigmob. Mob. Comput. Commun. Rev. 5, 3-55. doi: 10.1145/584091. 584093

Staley, J. T., and Gosink, J. J. (1999). Poles apart: biodiversity and biogeography of sea ice bacteria. Annu. Rev. Microbiol. 53, 189-215. doi: 10.1146/annurev. micro.53.1.189

Steindler, L., Schwalbach, M. S., Smith, D. P., Chan, F., and Giovannoni, S. J. (2011). Energy Starved Candidatus Pelagibacter Ubique substitutes light-mediated ATP production for endogenous carbon respiration. PLoS ONE 6:e19725. doi: 10.1371/journal.pone.0019725

Stingl, U., Desiderio, R. A., Cho, J. C., Vergin, K. L., and Giovannoni, S. J. (2007a). The SAR92 clade: an abundant coastal clade of culturable marine bacteria possessing proteorhodopsin. Appl. Environ. Microbiol. 73, 2290-2296. doi: 10.1128/AEM.02559-06

Stingl, U., Tripp, H. J., and Giovannoni, S. J. (2007b). Improvements of highthroughput culturing yielded novel SAR11 strains and other abundant marine bacteria from the Oregon coast and the Bermuda Atlantic time series study site. ISME J. 1, 361-371.

Suzuki, M. T., Preston, C. M., Chavez, F. P., and DeLong, E. F. (2001). Quantitative mapping of bacterioplankton populations in seawater: field tests across an upwelling plume in Monterey Bay. Aquat. Microb. Ecol. 24, 117-127. doi: 10.3354/ame024117

Suzuki, M. T., Taylor, L. T., and DeLong, E. F. (2000). Quantitative analysis of small-subunit rRNA genes in mixed microbial populations via 5'-nuclease assays. Appl. Environ. Microbiol. 66, 4605-4614. doi: 10.1128/AEM.66.11.46054614.2000

Teeling, H., Fuchs, B. M., Becher, D., Klockow, C., Gardebrecht, A., Bennke, C. M., et al. (2012). Substrate-controlled succession of marine bacterioplankton populations induced by a Phytoplankton Bloom. Science 336, 608-611. doi: $10.1126 /$ science. 1218344

Tremblay, J. É., Raimbault, P., Garcia, N., Lansard, B., Babin, M., and Gagnon, J. (2014). Impact of river discharge, upwelling and vertical mixing on the nutrient loading and productivity of the Canadian Beaufort Shelf. Biogeosciences 11, 4853-4868. doi: 10.5194/bg-11-48532014

Venter, J. C., Remington, K., Heidelberg, J. F., Halpern, A. L., Rusch, D., Eisen, J. A., et al. (2004). Environmental genome shotgun sequencing of the Sargasso Sea. Science 304, 66-74. doi: 10.1126/science.1093857

Yoshizawa, S., Kawanabe, A., Ito, H., Kandori, H., and Kogure, K. (2012). Diversity and functional analysis of proteorhodopsin in marine Flavobacteria. Environ. Microbiol. 14, 1240-1248. doi: 10.1111/j.1462-2920.2012. 02702.x

Conflict of Interest Statement: The authors declare that the research was conducted in the absence of any commercial or financial relationships that could be construed as a potential conflict of interest.

Copyright () 2016 Boeuf, Lami, Cunnington and Jeanthon. This is an open-access article distributed under the terms of the Creative Commons Attribution License (CC BY). The use, distribution or reproduction in other forums is permitted, provided the original author(s) or licensor are credited and that the original publication in this journal is cited, in accordance with accepted academic practice. No use, distribution or reproduction is permitted which does not comply with these terms. 